\title{
Benign Anal Granular Cell Tumor
}

National Cancer Institute

\section{Source}

National Cancer Institute. Benign Anal Granular Cell T umor. NCI Thesaurus. Code C5607.

A non-metastasizing neoplasm arising from the anus. It is characterized by the presence of large polygonal cells with abundant granular cytoplasm. 